\title{
Chantal Melis
}

\section{From topic marking to definite object marking}

\author{
Focusing on the beginnings of Spanish DOM
}

\begin{abstract}
The present work is a diachronic study of Differential Object Marking (DOM) in Spanish which focuses on the early stages of the grammaticalization process undergone by the $a$-marker. Following Pensado (1995), I relate DOM $a$ to the topicalizing function of Latin AD 'with regard to, as to', and then proceed to examine the step-by-step expansion of the grammaticalizing item, leading from personal pronouns to proper names and from these to definite common nouns of human reference. The central aim of the paper is to shed light on the specific properties associated with the distinct subsets of direct objects which were reached by DOM, under the assumption that these properties served to mediate shifts between categories and facilitated the development of a system governed by the semantic dimensions of animacy and definiteness, whose origins were tied to a parameter of information structure.
\end{abstract}

Keywords: Differential Object Marking (DOM), animacy, definiteness, grammaticalization, information structure, topicality

\section{Introduction}

Modern Spanish is a language with an extensive, dynamic and complex system of Differential Object Marking (DOM). ${ }^{1}$ At present, DOM in Spanish displays a basic distinction between human and non-human referents (Torrego Salcedo 1999, 1782; Leonetti 2004, 82; de Swart 2007, 132), according to which human-referring objects are regularly preceded by the case form $a$, while inanimate entities are generally unmarked (Torrego Salcedo 1999, 1781-1782): ${ }^{2}$

1 I owe thanks to two anonymous reviewers for invaluable comments on a previous version of this paper.

2 The distinction is usually couched in terms of an animate vs. inanimate opposition. The status of animate non-human direct objects, however, is not clear in Spanish (von Heusinger 2008, 4). Unlike the human-referring objects, which trigger DOM on a regular basis, the poorly document-

Chantal Melis, National Autonomous University of Mexico, e-mail: cme@unam.mx 
(1) a. Traj-eron a un amigo con ellos. bring-PFV.3PL ACC a friend with them 'They brought a friend with them.'

b. Traj-eron una maleta con ellos. bring-PFV.3PL a suitcase with them 'They brought a suitcase with them.'

The current situation is the result of an extended process of grammaticalization, whereby a-marking, much more restricted at earlier stages of the language, was allowed to spread to an increasing range of direct objects along a path usually held to have been governed by the familiar animacy and definiteness scales (Bossong 1985; Aissen 2003; Laca 2006). In general terms, $a$-marking, with a strong bias towards human entities throughout the history of Spanish, developed along the definiteness scale from higher-ranked definite objects to lower-ranked indefinite noun phrases until all human referents were reached.

Of particular interest in this diachronic scenario is the way in which definiteness and animacy were kept closely bound. By contrast, in many languages where definiteness is crucial for DOM, all higher-ranked entities on this dimension trigger marking, irrespective of animacy (Bossong 1991, 161; Aissen 2003, 53). This suggests that definiteness and animacy are independent parameters (de Swart 2007, 187). Indeed, according to Anagnostopoulou (1999, 789), the animacy restrictions imposed on the property of definiteness, as observed in Spanish, appear to relate to a "general mystery of natural languages", whereby "animacy plays a role in determining the 'degree' of definiteness of NPs for reasons that are not entirely clear”. On this view, then, an intriguing question raised by Spanish DOM has to do with the origin of the close relationship established between definiteness and humanhood.

Another issue of interest concerns the strong personal pronouns of Spanish, identified as the first set of direct objects that generalized an obligatory use of a-marking (Meier 1948; Ramsden 1961; Fernández Ramírez 1964; Rohlfs 1971). To explain the leading role of these forms in the grammaticalization process of DOM, scholars invoke the animacy scale (e.g. Comrie 1989, 128; Bossong 1991, 159) or the definiteness scale (Aissen 2003, 444; von Heusinger 2008, 5), on which the personal pronouns are located at the respective top ends. In neither case, of course, the pronouns can be regarded as more "animate" or more "definite" than lower-ranked sets of direct objects, such as, for example, definite common

ed category of animals shows highly optional marking (cf. García García 2018, 217-218 for discussion). 
nouns of human reference. In fact, reflecting on the cross-linguistic preference of DOM for pronouns, Comrie $(1989,198)$ wonders whether the relevant criterion might not rather be conceived of in terms of a "hierarchy of topic-worthiness". This hypothesis concurs with a number of recent proposals in which topicality is claimed to be the driving force behind the emergence and development of DOM systems (Escandell Vidal 2009; Iemmolo 2010; Dalrymple/Nikolaeva 2011; Iemmolo/Klumpp 2014; Witzlack-Makarevich/Seržant 2018). The notion of topicality has also been brought up in relation to Spanish DOM, particularly when the oldest instances of $a$-marking are examined (Melis 1995; Pensado 1995; Laca 2006). However, as noted in García García $(2018,216)$, the extent to which topicality may satisfactorily account for the entire evolution of $a$ is not clear, although attempts in this direction have been made: one could argue, for instance, that the basic function of $a$ is, and has always been, to mark direct objects as internal (secondary) topics (Leonetti 2004), or $a$-marking could be interpreted as a strategy for highlighting discourse prominent and, in this sense, highly topical objects (Laca 1995). Nevertheless, assuming that topicality played a role in the evolution of Spanish DOM, what remains to be outlined is the diachronic path along which the referential properties of animacy and definiteness were brought to interact with the pragmatic dimension of topicality.

Another matter deserving of attention relates to the commonly held view that systems of DOM arise in response to the need to disambiguate grammatical relations in transitive clauses. This is the sense in which the so-called "distinguishing" or "discriminatory" function of case marking (Malchukov/de Swart 2009; Siewierska/Bakker 2009) is applied to DOM: direct objects which, owing to some of their associated properties, run the risk of being confused with subjects trigger marking. Ambiguity avoidance is also claimed to have inspired the original recourse to DOM in Spanish, according to a long-standing hypothesis (Müller 1971) which continues to draw support in the literature (e.g. de Swart 2007, 142-147). The trouble with this claim is that it does not suit the oldest data of $a$-marking, since the personal pronouns, first targeted by DOM, displayed unmistakable object forms ( $m i$, $t i$, etc. vs. nominative yo, tú, etc.) and were very unlikely to generate confusion. This has been observed in a number of studies (Pensado 1995, 191; Bossong 1998, 223; cf. Aissen 2003, 437), in light of which the initial motivation for differential marking in Spanish seems worth examining in greater detail.

Finally, the $a$-marker itself has to be looked at more closely. On the surface, the device used for DOM is identical to the case marker which obligatorily precedes all indirect object noun phrases in Spanish. The coincidence in form between DOM $a$ and dative $a$ lies at the bottom of the prevailing consensus that the dative preposition was employed for Differential Object Marking. This consensus has been strengthened by cross-linguistic findings regarding similar ten- 
dencies in a variety of DOM systems (Bossong 1991). Nonetheless, an alternative view does exist, according to which the $a$-marker in Spanish (and other Romance languages) goes back to the topicalizing use of the Latin preposition AD meaning 'with regard to, as to', as argued in Iemmolo (2010), with reference to Pensado (1995), who developed this proposal in an important paper a couple of decades ago. Exploring the history of Spanish DOM from the vantage point of this challenging hypothesis is a task which is worth to be taken up.

The pending questions concerning Spanish DOM bring to mind recent typological publications which show that the factors conditioning split case alternations are far more diverse across and within linguistic families than generally supposed (Bickel/Witzlak-Makarevich 2008; Bickel/Witzlak-Makarevich/Zakharko 2015; cf. also Sinnemäki 2014). For a deeper understanding of the attested heterogeneity, it is concluded, fine-grained diachronic studies should be carried out exploring the idiosyncratic ways in which individual systems of Differential Object Marking arise, develop and mature (Bickel/Witzlak-Makarevich 2008, 33).

My aim in the present work is to shed light on the peculiarities of Spanish DOM, focusing on the early stages of its development and watching for details of the unfolding evolutionary path of $a$-marking. I will situate the source of the marker in the topicalizing use of the Latin preposition $\mathrm{AD}$ 'with regard to, as to', following Pensado (1995), and I will then proceed to examine the beginnings of the process of grammaticalization. As is customary in functional approaches, a gradual type of expansion will be expected, moving through a sequence of stepby-step changes associated with the spread of the original form to new environments (Traugott/Trousdale 2010). In this process, the element undergoing grammaticalization develops new functions which imply more and more distancing with respect to the lexical value of the source item (García/van Putte 1987, 373; Lichtenberk 1991, 76). Grammaticalizing $a$ will give us the opportunity to plot a movement of this nature, departing from contexts with features of meaning closely related to the sense of the original topic-marker and extending to contexts where topicality fades out and new functions linked to referential properties emerge.

The chapter is organized as follows. In Section 2 I summarize Pensado's (1995) proposal regarding the topicalizing construction that gave rise to DOM in Spanish. Section 3 discusses the grammaticalization of $a$ with the strong personal pronouns and postulates a shift from a notion of topicality to a feature of discourse prominence. Section 4 deals with the extension of obligatory DOM to proper names of human reference, which had the effect of turning individuation into a crucial factor for marking. In Section 5 I examine the incipient spread of $a$ to human common nouns, as reflected in the epic poem Cantar de mio Cid, written around 1200, where singularity is found to outweigh definiteness and 
topicalized objects verify the origin of the $a$-marker. Section 6 sketches the subsequent diffusion of $a$ to the entire class of human objects and briefly touches upon the interacting parameter of verbal semantics. The paper ends with a short conclusion in Section 7.

\section{The source of Spanish DOM: topicalizing Latin AD}

As mentioned in the Introduction, DOM-marked objects in Spanish carry a case form which is identical to the preposition introducing indirect object noun phrases. The tendency for DOM and dative markers to converge is a recurrent phenomenon cross-linguistically (Bossong 1991, 157), susceptible of being explained if one considers that "direct and indirect objects are structurally similar in being non-subject arguments", in conjunction with the fact that "indirect objects are overwhelmingly human (or animate) and definite, exactly the properties which favor DOM for direct objects" (Aissen 2003, 446-447, note 10). With regard to Spanish, it is important to underline that the similarly marked arguments behave differently from a syntactic point of view. ${ }^{3}$

DOM markers, evidently, may have other sources (Bossong 1991, 167, note 41). Within the Romance family, for example, Romanian pe 'on' (< Lat. PER) used for DOM is a preposition of locative origin which bears no resemblance to the morphological dative case form, while in other languages, discussed in Iemmolo (2010, 262-265), the marker appearing on a subset of direct objects (and covering some locative and dative functions as well) conveys a basic sense of "aboutness". The topical features associated with the latter type are particularly relevant to our study, considering that a couple of decades ago Pensado (1995) put forward a hypothesis as to the origin of the $a$-marker of Spanish which likewise appeals to a notion of topicality. Most significantly, her historical reconstruction, to be summarized in a moment, leads to the establishment of a clear distinction between dative $a$-developed from the directional uses ('to, towards') of the Latin preposition $\mathrm{AD}$ - and DOM $a$ - deriving from the topicalizing function ('with regard to, as to') of the same Latin etymon -, which imposes a new perspective on the way in

3 The differences mentioned in Bossong $(1991,155)$ include the differential use of DOM $a$ versus the compulsory use of dative $a$, the occurrence of DOM-marked objects with transitive verbs, and the pronominalization of the two types of object with distinct clitics. Moreover, DOM-marked objects and dative objects in Spanish contrast with respect to phenomena such as passivization, nominal modification and depictive secondary predicates (Bárány 2016). 
which a system of Differential Object Marking was introduced into the language. Studies on Spanish DOM now often cite Pensado's work to express agreement with her proposal (Torrego Salcedo 1999; Leonetti 2004; Escandell Vidal 2009; Iemmolo 2010), although the full implications of this novel and challenging view have not received due attention.

According to Pensado (1995), the marker recruited for DOM in Spanish goes back to the use of Latin AD in contexts where the preposition, meaning 'with regard to, as to', served to indicate a shift of topic. ${ }^{4}$ Basing her proposal on a careful examination of late Latin and early Romance data, Pensado reconstructs an evolutionary path along which the topicalizing function of AD was passed on to some of the Romance dialects, where the inherited structure appears to have been initially reserved for the personal pronouns of first and second person, that is, for the speech act participants. In classical Latin, AD governed accusative case, but due to the gradual erosion of the case marking system which is known to have taken place in the transition period between Latin and Romance, and as a result of the merging processes which it occasioned, in late Latin combinations of $\mathrm{AD}$ and the dative case form of the pronouns began to emerge $\left(\mathrm{AD}+\mathrm{MIHI}_{\mathrm{DAT}}\right) .^{5}$ This use is well attested in Late Latin textual sources (Müller 1971, 494-495), and Pensado conjectures that it was introduced in the topicalizing structures, irrespective of whether the dislocated pronominal constituent fulfilled the role of direct or indirect object in the main clause (Pensado 1995, 203):

(2) Ad mihi, (mihi) dixit 'As to me, he told (me)'

Ad mihi, (me) amat 'As to me, he loves (me)'

The hypothesis that the differential object marker $a$ of Spanish and other Romance languages developed from the topicalizing function of $\mathrm{AD}$ with the personal pronouns of first and second person singular illuminates the contrast existing between DOM languages, like Spanish, and non-DOM languages,

\footnotetext{
4 The topicalizing function of Latin AD manifests itself in examples where the topic shifter forms part of a larger phrase (quod ad me attinet, $X$ 'as far as I am concerned, X'; quod ad Xenonem, $X$ 'as for Xenon, $X$ '), and in contexts where it is used alone (ad ea autem, quae scribis de testamento, $X$ 'with regard to what you write about the will, X') (Pensado 1995, 200-201).

5 In the nominal area, the dative case was replaced by $\mathrm{AD}+$ accusative for the expression of the indirect object function ( $a d$ filios tuos 'to, for your children'), and the nominal pattern appears to have acted as the model for the extension of the preposition to the personal pronouns, in spite of the fact that these were marked as dative and did not need the preposition to display their case (Dixit spiritus ad mihi 'the holy spirit said to me') (Pensado 1995, 184-185).
} 
like French. The difference in question has to do with the well-known divergence of the Romance pronominal system into stressed - strong or tonic - and unstressed - weak or atonic - forms. Under Pensado's analysis, the dialects which developed the use of a mí (< AD MIHI) in pragmatically marked constructions retained the dative ancestors for a longer time and made them serve as exponents of the stressed series of pronominal forms (ACC/DAT $a$ mi and $a$ ti), as opposed to the unstressed forms (ACC/DAT me and te), which were derived from the Latin accusative. ${ }^{6}$ By contrast, in the dialects where topicalizing AD does not appear to have taken root, dative MIHI and TIBI were lost at an earlier date and the accusative paradigm of Latin provided the source for both the weak (Lat. ME $>$ Fr. me) and the strong (Lat. ME > Fr. moi) pronouns (Pensado 1995, 180-181; cf. Harris 1978, 102-103).

Additionally, the conjecture that the topicalizing structures with $a$ were initially limited to the speech act participants gains support from looking at the stressed forms of the third person pronouns (él 'him', ella 'her', etc.), which for the most part descend from Latin accusatives (of the paradigm of demonstrative pronouns) and, unlike mí and $t i$, are not dative. In other words, DOM marking on the Spanish third person stressed object pronouns (ACC/DAT a él, a ella, etc.) must have spread at some later point in history, after the split between stressed and unstressed forms (Pensado 1995, 194-195). ${ }^{7}$

The hypothesis advanced by Pensado is very much in line with the growing body of research on the fundamental role topicality is assumed to play in the emergence and development of DOM systems across the world (Escandell Vidal 2009; Iemmolo 2010; Dalrymple/Nikolaeva 2011; Iemmolo/Klumpp 2014; WitzlackMakarevich/Seržant 2018). Worthy of note is the supporting evidence her hypothesis receives from a group of Romance dialects, where a presently incipient system of DOM is targeting topical objects appearing in left- or right-dislocation structures (Escandell Vidal 2009; Iemmolo 2010).

When DOM arises in these pragmatically marked constructions, future events may take different courses: in some languages DOM remains confined to topical objects, whereas in other languages DOM is extended to non-topical objects (Iemmolo 2010, 247; cf. Dalrymple/Nikolaeva 2011). If extended, DOM loosens

\footnotetext{
6 Scholars assume that the ACC/DAT syncretism in the unstressed pronouns was created by analogy with the stressed forms (Folgar 1993, 52).

7 The personal pronouns of first and second person plural show a similar phenomenon: their stressed and unstressed forms jointly derive from the Latin nominative/accusative (Pensado 1995, 194). This corroborates Pensado's hypothesis that the topicalizing source of DOM $a$ was linked to the pronouns of the singular first and second persons.
} 
its ties to information structure and becomes sensitive to the presence of "topicworthiness" features, which often translate into semantic factors such as animacy and definiteness (Iemmolo 2010, 257). In what follows, an attempt will be made to spell out the details of this general scenario in relation to Spanish.

\section{Personal pronouns at the first stage of the grammaticalization process}

In the literature on Spanish DOM it has long been noted that the first targets of grammaticalizing $a$ were the stressed object personal pronouns (Meier 1948; Ramsden 1961; Fernández Ramírez 1964; Rohlfs 1971). The oldest sources manifesting a regular use of DOM with these pronouns are Mozarabic texts of the Iberian Peninsula dating back to the $11^{\text {th }}$ and $12^{\text {th }}$ centuries (Bossong 1998, 223-224). Additional evidence emanates from the epic poem Cantar de mio Cid (early $13^{\text {th }}$ century), in which the referred pronouns are always $a$-marked, regardless of their position in the clause. Some topicalized pronouns occur initially (3a), but others occupy the postverbal slot typical of direct object noun phrases (3b): ${ }^{8}$

(3) a. a ti adoro credo de toda voluntad ACC 2SG worship.PRS.1SG and believe.PRS.1SG of all goodwill 'I worship you and believe in you with all my heart.' (v. 362)

b. Oí-d a mí, Álbar Fáñez e todos los cavalleros listen-IMP ACC 1SG Alvar Fañez and all the knights 'Alvar Fañez and all the knights, listen to me.' (v. 616)

Our discussion of the grammaticalization process undergone by $a$ has to start by stressing that DOM was not implemented for the purpose of disambiguating participant roles. This seems clear since the objects encoded in mi and ti are overtly marked as accusative forms and are not liable to being confused with their subjective counterparts (yo and tú, respectively). Ambiguity avoidance defines one of the oldest hypotheses invoked in the literature to explain the origin of Spanish DOM (Müller 1971) and continues to draw scholarly approval (de Swart 2007,

8 The examples of the Cid are cited from Montaner's (1993) edition. 
142-147; Malchukov/de Swart 2009, 349). ${ }^{9}$ As noted in various studies, however, the pronominal data associated with the oldest phase of the grammaticalization process militate against this hypothesis (Pensado 1995, 191; Bossong 1998, 223; cf. Aissen 2003, 437).

From a different perspective, the personal pronouns are natural candidates to attract differential marking at the initial stage, given their position in the hierarchies of animacy and definiteness which are held to regulate DOM crosslinguistically (Comrie 1979; Bossong 1985; Lazard 1998; Aissen 2003). These hierarchies, as is well known, organize discourse entities in accordance with the likelihood of their appearance as subjects (high end) or objects (low end) in bivalent clauses. Independently of whether the personal pronouns are situated on the animacy (Comrie 1989, 128; Bossong 1991, 159) or definiteness scale (Aissen 2003, 444; von Heusinger 2008, 5), they are treated as conforming the highest-ranked category of elements, optimally predisposed to function as subjects. Consequently, if the iconic motivation for DOM is to mark objects sharing properties with prototypical subjects, that is, semantically marked objects (Comrie 1989, 128; Bossong 1991, 162; Aissen 2003, 438), personal pronouns cast in the direct object role have to be viewed as prime triggers of differential marking.

On a third approach, embodied in studies which relate the genesis of DOM systems to topicalizations in dislocated constructions, the extension to the personal pronouns at the beginning stage of the grammaticalization process is justified on the grounds that the members of this category are "highly topical" (Iemmolo 2010, 258). It is also pointed out that the notion of topicality meshes with the referential dimensions of animacy and definiteness insofar as "prototypical topics are usually definite, specific and animate” (Escandell Vidal 2009, 836).

9 Actually, the disambiguating hypothesis is supposed to account for the emergence of DOM systems across languages (Malchukov 2008). In this view, DOM arises with a context-dependent (global) function of discrimination, when subject and object require disambiguation, and develops into a processing-wise less costly system of context-independent (local) discrimination, which no longer relies on a comparison of the object with the subject of the sentence, but shows a generalized type of marking appearing on certain classes of referents. In accordance with this scenario, it can then be explained why there do not exist many differential marking systems that seem to perform a purely disambiguating function (Malchukov 2008; Witzlack-Makarevich/ Seržant 2018): disambiguation captures what sets DOM systems in motion and continues to operate as "a weak universal force", surfacing on occasion in some contexts of use, but subordinated to other processes (Seržant 2019). As said, the hypothesis does not concur with the data of incipient DOM in Spanish, but this does not rule out the possibility that, once introduced into the language, the new device was called upon to distinguish objects from subjects in specific contexts where clarification was necessary or highly desirable. 
The relevant question here is what it means to be "topical". If we interpret topic as characterizing the entity "which the proposition expressed by the sentence is ABOUT" (Lambrecht 1994, 118), the definition applies to constituents which have topic status in particular syntactic environments. But personal pronouns are not necessarily topical in this sense, because they may also appear in the focus domain of an utterance, as part of the comment or as the sole constituent in focus (Lambrecht 1994, 128-130). And it is reasonable to assume that, in some instances, the DOM-marked personal pronouns of Spanish stood in a focal relationship to the proposition.

At the same time, theories of grammaticalization predict that the first context to which the grammaticalizing element is extended will show a high degree of compatibility with the original value of the lexical source (García/van Putte 1987, 373; Lichtenberk 1991, 76). Our task thus consists in identifying meaning properties which could have facilitated the passage from topicalizing $a(d)$ to $a$-marking on all personal pronouns, regardless of whether the initial targets of DOM functioned as clausal topics or not.

I suggest that these properties may be localized in the general condition of prominence that is attributed to the pronouns (Anagnastopoulou 1999, 770). The condition is defined as involving both "familiarity" and being in the current centre of attention, that is, being "active” in Chafe's (1987) terms. Since both speech act participants ( $a$ mí, $a$ ti) and anaphoric third parties ( $a$ él, a ella, etc.) conform to this description, the functional change experienced by $a$ can be specified by means of a concept of prominence: the topicalizing marker severed its ties to information structure and moved in the direction of a more broadly conceived dimension of communicative importance, i.e. being familiar and active at the moment of utterance.

For the future development of grammaticalizing $a$, two additional pieces of information need to be taken into account. The first one bears on the emphatic character of the strong personal pronouns of Spanish. The weak (clitic) object pronouns ( $m e$, te, lo, etc.) predominate in discourse, because they are given the task of encoding the personal referents in normal circumstances. The strong pronouns, on the other hand, are used occasionally in contexts where some kind of special contrastive effect is intended; they signal an explicit or implicit attempt on the part of the speaker to compare or oppose the individual in question to other referents (Luján 1999). This leads to the recognition that Spanish DOM initiates its trajectory in association with a special class of marked forms, to which an appeal is made when the distinct identity of the highlighted participant matters to a considerable degree. We will see below that issues of referential identity will soon be moved into the foreground. 
Secondly, one needs to be aware of the fact that the stressed personal pronouns of Spanish in (subject and) object function only refer to persons and never to inanimate entities (Luján 1999, 1294; Ramsden 1961). Pronouns in general are not restricted in this way, but this feature will turn out to be instrumental in maintaining the preference of $a$-marking for human beings throughout the evolution of Spanish DOM.

In sum, the first step in the process under analysis reveals a pathway of change moving from pragmatically marked constructions, at the information structure level, towards marked pronominal forms of special communicative importance. As topicalized objects in the source constructions, the pronouns were assigned the role of acting as subjective "viewpoints" (DeLancey 1981) from which speakers chose to report the event (cf. Section 5 below). ${ }^{10}$ The first step towards the establishment of a grammaticalized system of differential marking consisted in extending topicalizing $a$ to prominent - familiar, activated and, in the case of Spanish, strictly human - entities embedded in discourse contexts in which their unique identity, as opposed to that of others, turned out to be exceptionally relevant.

\section{From personal pronouns to personal names}

Human-referring proper names were next in motivating a compulsory use of $a$ (Müller 1971; Folgar 1993), that is, DOM was extended from the pronominal domain to the nominal category. This represents an important shift, interpretable as indicative of the fact that topical values are fading out. Indeed, compared with pronouns, lexically coded objects are less likely to enjoy the status of active discourse participants at the moment of utterance and hence less likely to function as aboutness topics (according to the topic acceptability scale: Givón 1983, 18; Lambrecht 1994, 165).

Evidence for the second stage of the grammaticalization process is provided by the Cantar de mio Cid, in which, beyond the personal pronouns, proper names of human reference are alone in showing obligatory marking wherever they occur: ${ }^{11}$

10 DeLancey (1981, 637, note 17) alludes to the relation existing between the category of viewpoint and topicality.

11 Toponyms, by contrast, are only optionally marked (Monedero Carrillo de Albornoz 1978). It should be pointed out that human names yield one pragmatically motivated omission of $a$ discussed in García/van Putte (1987). 
(4) los braços abiertos, recibe a Minaya the arms open receives Acc Minaya 'With open arms, he welcomes Minaya.' (v. 489)

Why proper names were reached before common nouns by grammaticalizing $a$ is often explained with an appeal to the hierarchies of animacy and definiteness. On these hierarchies, proper names are placed at the higher end (following pronouns and preceding common nouns) to reflect the fact that DOM-based splits across languages show a tendency to treat proper names as more animate (Comrie 1989, 186) or more definite (Aissen 2003, 443) than common nouns. ${ }^{12}$

Bearing in mind that $a$ was extended to definite common nouns at the next stage (cf. Section 5), we are justified in exploring to what extent the definiteness dimension can account for the expansion of Spanish DOM to proper names. Definiteness is a complex notion, in which a component of familiarity - the referent is assumed to be identifiable to the addressee - interacts with an idea of uniqueness - there exists one entity (or one set of entities) which satisfies the description. As stated in the literature, definite noun phrases do not always carry these values (cf. Belloro 2007, 110), but it can still be argued that, in the clearest or more typical case, definite expressions encode uniquely identifiable referents.

Proper names are definite in this sense. They are characterized by a feature of uniqueness, "since they involve only a single individual, a class of one member", and may therefore be considered as "the epitome of individuation" (Kliffer 1984, 199). However, referring uniquely to an individual is not a property associated with proper names alone. This function is shared by (the singular set of) personal pronouns, as well as by definite singular common nouns, with which $a$ generalized at a much later date. Why the separate treatment then? Proper names appear to have played a mediating role in the shift from pronouns to common nouns for some reason to be elucidated.

The plausible explanation points to a couple of features which link proper names with personal pronouns and oppose them to definite nouns. From a semantic point of view, personal pronouns and proper names are alike in carrying little information beyond the designation of an individual (Laca 1995, 82); common nouns have categorial meaning. On the formal level, the personal pronouns are inherently definite forms, unlike the common nouns, which, by contrast, depend

12 Aissen $(2003,444)$ suggests that the ordering of elements on the definiteness scale (PRONOUN $>$ NAME $>$ DEFINITE $>$ INDEFINITE SPECIFIC > NON-SPECIFIC) has to do with the extent to which the value assigned to the discourse referent is fixed. It is fixed by the speech situation in the case of pronouns and by convention in the case of proper names. Definite descriptions, by comparison, rely on previous discourse, and indefinites allow for greater freedom in fixing their value. 
on the presence of some determiner to transform into definite referential expressions (Siewierska 2004, 10), ${ }^{13}$ and from this point of view, proper names side with pronouns, against common nouns, given their capacity of introducing definite referents without the support of overt modification (Lambrecht 1994, 87).

In grammaticalization processes, new functions develop from older functions one after the other, in a sequence of small steps that imply more and more distancing from the original value of the source item (García/van Putte 1987, 373; Lichtenberk 1991, 76). Recent work on grammaticalization has brought analogy back into the limelight to explain how such movements from one context to another take place. Analogy thrives on relations of similarity, in form, meaning or grammatical function, which are perceived by speakers and operate as major mechanisms in determining pathways of change (De Smet 2012; Fischer 2013, among others). Note how analogy likewise enables us to clarify the role played by proper names in the expansion of grammaticalizing $a$ : DOM proceeded to definite noun phrases which by themselves, without determiners, like the personal pronouns, designate unique referents.

The new targets of DOM have brought individuation to the fore as a crucial factor for marking. The continuity with the previous stage is easy to see if we recall that the emphatic pronominal contexts were exceptionally concerned with the individuality of the referent, understood in the sense of having a distinct identity, of being that person and no other (Laca 1995, 82). But concomitantly, as expected, the functional load of $a$ has been shifted. The marked objects, indeed, are no longer required to encode active participants; the degree of necessary prominence has been lowered. Neither are they pragmatically marked forms in the way the emphatic pronouns were. These changes signal that discourserelated conditions are losing their grip on the marking, while opening the way for the interaction of DOM with a hierarchy of individuation, which, following Comrie $(1989,199)$, may be equated with a hierarchy of salience, since "[s]alience relates to the way in which certain aspects present in a situation are seized upon by humans as foci of attention, only subsequently attention being paid to less salient, less individuated objects". Hence, at this second stage, saliency in terms of standing out as a distinct, single, separate entity is now sufficient to induce $a$.

13 According to Siewierska $(2004,124)$, a primary feature of the personal pronouns is "necessary referentiality and even definiteness", reflected in the fact that these forms "typically cannot occur with definite determiners, or indefinite articles, be construed as bound variables or receive a non-specific or generic interpretation”. 


\section{Extension to definite common nouns}

The Cantar de mio Cid affords a picture of the incipient expansion of DOM to human-referring common nouns. In contrast to personal pronouns and proper names, which are always preceded by $a$, common noun phrases are optionally marked. Melis (1995) reports a global frequency of $36 \%$ of marking on these objects (68/187) and illustrates the variation with examples such as in (5):

(5) a. Casastes sus fijas con ifantes de Carrión
marry.PFV.2sG his daughters with infantes of Carrion
'You married his daughters to the infantes of Carrion.' (v. 2939)
b. reciba $\quad$ a mios yernos commo él pudier
receive.IMP.2SG ACC my sons-in-law as he can.prs.cond.3sg
mejor
better
'Let him give my sons-in-law the best possible welcome.' (v. 2637)

As discussed in diachronic studies on Spanish DOM, the diffusion of $a$ among common nouns was a gradual process which took many centuries before culminating in near obligatory marking on all human objects, with definite nouns being clearly favoured during the earlier phases of this process (Company Company 2002b; Laca 2006; von Heusinger/Kaiser 2011; García García 2018).

The sensitivity of DOM to definite nouns at the beginning of the third stage can be verified in the Cid, where definite human objects trigger $a$ in 46\% (50/109) of their uses, as compared to $22 \%$ (19/88) of marked indefinite human nouns (García/van Putte 1987, 376; cf. Laca 2006, 441, with results based on a partial revision of the poem). Moreover, when a number distinction is taken into account, it is observed that singular definite human objects motivate DOM with the highest frequency $(14 / 19=74 \%)$ (García/van Putte 1987, 376). This comes as no surprise, given the proximity of this subgroup to proper names; in both cases, the object refers to a uniquely identifiable human being.

What the epic poem additionally reveals, somewhat unexpectedly, is that plural definite nouns $(36 / 90=40 \%$ of $a)$ and singular indefinite nouns $(7 / 20=$ $36 \%$ of $a$ ) share a similar distribution of optional marking (García/van Putte 1987, 376). These findings suggest that the parameter of singularity competes in a significant way with the definite dimension. In fact, as Garcia/Van Putte (1987) demonstrate via a calculus of relative weights, singular number in the Cid turns out to be more influential than definiteness as the relevant factor for DOM.

Cross-linguistically, DOM systems have a tendency to introduce a singularplural opposition in noun phrases higher in animacy and not in lower ranked 
(inanimate) categories. Comrie $(1989,189)$ proposes that the correlation between number distinctions and animacy may be seen as "reflecting greater human concern with entities of higher animacy as individuals, therefore countable, while entities of lower animacy are more readily perceived as an indeterminate class”. According to Bickel/Witzlak-Makarevich/Zakharko (2015, 17), the selection of singular over plural referents in differential marking systems "is based on the assumption that singular is more indexible than nonsingular and therefore ranks higher: singular items can be better pointed at than other referents". As is clear, in one way or another, these explanations lead back to the hierarchy of salience, presented above, in regard to which Comrie $(1989,199)$ brings to attention that "work on salience indicates that singular entities are more salient than plural entities".

From this perspective, the precedence taken by singularity over definiteness in the Cid's optional markings on human common nouns is easy to interpret. What underlies these uses is the criterion of individuation ushered in by proper names (cf. Section 4 above). We are witnessing a grammaticalization process that is unfolding step by step through the mediation of similarities and continuities: in the expansion from proper names to definite common nouns, singularity has had the role of acting as a factor of transition.

At the same time, there is evidence that grammaticalizing $a$ has not been fully bleached of its original lexical sense in the Cid. Significantly, indeed, in approximately half of the DOM marked examples, the human common nouns occur in topicalizing structures, with the object detached to the left periphery and usually accompanied by a coreferential weak pronoun (Melis 1995; 2018; Laca 2006). Note how a paraphrasis of (6) in terms of 'as to his daughters, he took them in his arms' is still available:

$\begin{array}{lllll}a \quad \text { las sus fijas en braços las } & \text { prendia } \\ \text { ACC the his daughters in arms ACC.FEM.PL } & \text { took.3sG } \\ \text { 'He embraced his daughters.' (v. 275) } & \end{array}$

Left-and right-dislocated structures are widely used in the Cid (Menéndez Pidal 1964, 323). It is possible that they should be viewed as lingering traces of the oral tradition that is assumed to have given shape to the epic poem, considering that in later medieval texts dislocations become extremely rare and objects affected by DOM are no longer topicalized in this way (Laca 2006, 471). One could therefore argue that the frequency with which common noun objects appear in topicalizations has more to do with general principles governing the architecture of the epic poem than with the original function of the preposition that gave rise to DOM. However, if this were the case, one would expect a similar distribution of topi- 
calized entities across the object category. But this does not happen: whereas the obligatorily marked personal pronouns and proper names appear left-dislocated in a quarter of their uses, the human common nouns marked with $a$, as I said, motivate the topicalizing strategy in half of the registered examples. ${ }^{14}$ The inference to be drawn from this contrast is that the common nouns are still very much dependent on pragmatically marked constructions to license a DOM-driven split.

I will use example (6) for a brief reflection on the informative status of the topicalized object. This matter deserves a moment of attention, because studies on DOM, in which the origin of differential marking has been explicitly related to mechanisms of topicalization, disagree as to whether the promoted object in these constructions assumes the role of primary (Iemmolo 2010) or secondary (Dalrymple/Nikoaleva 2011) topic. My proposal is to look at (6) to see if it can help us resolve the debate. We begin by noting that the participants present in the depicted scene are the Cid and his daughters. The father appears as the grammatical subject of the clause, anaphorically encoded in the verbal suffix and clearly functioning as primary topic, in light of which, the daughters, notwithstanding their communicative importance, have to be interpreted as secondary topic. Sentences with two topics are not uncommon. According to Lambrecht $(1994,148)$, a sentence of this nature "in addition to conveying information about the topic referents, conveys information ABOUT THE RELATION that holds between them as arguments in the proposition" (cf. Nikolaeva 2001). The relation holding between two topical participants can be expressed in a variety of sentential forms (Lambrecht 1994). What explains the marked character of structures like (6) is that the secondary topic is given the highest degree of pragmatic prominence among the participants, by being chosen as the viewpoint (DeLancey 1981) from which the event - a loving embrace between father and daughters - is described.

It is important to realize that the hypothesis of secondary topic in no way collides with the role Iemmolo (2010) attributes to this type of dislocated structures in his proposal about the emergence of DOM systems. Certainly, there will be cases in which the dislocated object does indeed function as primary topic, with the subject pertaining to the focal portion of the clause, but more commonly there will be a topical subject in relation to which the object defines a secondary topic.

The dislocated examples of the Cid are precious data lending full support to the topicality origins of Spanish DOM. Although the situation reflected by the epic poem displays a phenomenon of grammaticalization already in process, accom-

14 In my data sample of the Cid, personal pronouns functioning as direct objects appear topicalized in $27 \%$ of their occurrences (4/15) and proper names of human beings in $26 \%$ of the extracted tokens (14/54). DOM-marked common nouns of human reference yield $46 \%$ of topicalizations (31/68). 
panied by the development of new conditioning factors such as discourse prominence and semantic individuation, the topicalizations involving common nouns are contexts in which the source sense of $a(d)$ 'with regard to, as to' remains visible and active. The co-existence of the preposition's older and newer functions within the poem exemplifies the principle of layering discussed in Hopper's (1991) work on grammaticalization and can easily be accounted for.

\section{Evolution of DOM}

In medieval texts posterior to the Cantar de mio Cid, marking on human-referring common nouns continues to be optional, with the difference, as mentioned above, that objects triggering DOM are rarely topicalized. The diachronic data also suggest that the criterion of singularity, prevailing in the epic poem, eventually gave way to that of definiteness.

Historical studies of Spanish DOM have outlined an evolutionary path roughly divisible into three major phases: optional $a$ favours human definite objects during the Middle Ages; a fairly regular use of DOM with these objects is established in Renaissance Spanish, at a time when indefinite human objects are marked in about half of their occurrences; $a$ becomes the norm with the indefinite group in the modern period of the language (for statistical data supporting this division, cf. von Heusinger/Kaiser 2005, 45; 2011, 602; Laca 2006, 442-443; von Heusinger 2008, 14; García García 2018, 214-215). ${ }^{15}$

What García/van Putte (1987) have added to this picture is a proof of the shift from singularity to definiteness that took place during the medieval era. This is achieved by means of a comparison between the Cantar de mio Cid and Cervantes' Quijote (early $17^{\text {th }}$ century), which shows, via a similar calculus of relative weights (cf. Section 5), that in the later text definiteness has come to weigh more heavily on the operation of DOM than singular number. That is to say, objects encoding identifiable human referents have gained the upper hand as preferred attractors of DOM, regardless of whether the objects denote individuals or correspond to definite sets of plural membership.

15 As explicitly set forth in the cited papers of von Heusinger and colleagues, a more accurate description of this evolution has to take the parameter of specificity into account, introducing a division between specific indefinite and non-specific indefinite human objects. The latter continue to license optional marking in modern Spanish (Leonetti 2004, 80; von Heusinger 2008, 5). For a good discussion of specificity effects on Spanish DOM, cf. von Heusinger/Kaiser 2003). 
The attraction of plural definite nouns to the domain of DOM evidences an increase in the schematic value of $a$, to the extent that the feature of salience associated with individuated entities is growing more obscure and is giving way to a less restrictive condition stipulating that the referent solely be identifiable to the addressee. Within the framework of a markedness approach to DOM - objects resembling subjects have marked properties which motivate iconic patterns of marked encoding (Bossong 1991; Aissen 2003), the changes we have analyzed appear to have evolved on a par with a progressively wider conception of what it means to be "subject-like", as reflected in the outlined path of grammaticalization: CLAUSAL TOPIC > PROMINENT DISCOURSE PARTICIPANT > UNIQUELY SALIENT INDIVIDUAL > IDENTIFIABLE REFERENT. In each step, as we notice, the marking value of $a$ is expanded to embrace successively larger sets of properties and is thereby brought closer and closer to profiling a more general type of entity, capable of filling the grammatical slot of subject in accordance with speakers' expectations.

In present-day Spanish, the category of objects viewed as subject-like now comprises all human beings, as a result of the downward movement of DOM along the definiteness scale. By contrast, the lower-ranked objects on the animacy scale - non-human animate and inanimate objects - do not seem to have participated in the diachronic expansion of $a$. Optional uses of marking are registered throughout the centuries, but they remain marginal, with no sign of perceptible growth. Of the scarcely documented non-human animate objects nothing significant can be stated (for some discussion, cf. García García 2018, 217-218). Inanimate entities, on the other hand, frequent in all textual sources, yield a clear panorama of uncommon marking. The suggestion (Company Company 2002a; 2002b) that DOM has begun to extend to inanimate objects does not appear to encounter much support in empirical data (cf. García García 2018 and references therein; cf. also von Heusinger/Kaiser 2005).

The distinction between human and non-human objects characterizing Spanish DOM in its present state determines case marking splits in other languages (Comrie 1989, 195). Drawing on the markedness theory, it may be sufficient to observe that in prototypical transitive clauses the subject is high in animacy and the object is lower in animacy (Comrie 1989, 128) in order to explain why DOM prefers human (subject-like) referents. But in the case of Spanish, matters are not straightforward, because definiteness was crucially involved in the evolution of $a$ and could have affected inanimate objects as well. As mentioned in the Introduction, indeed, animacy and definiteness are independent dimensions that need not work hand in hand. The fact that in Spanish they did so may be attributed to a couple of motives.

One of these points to a phenomenon of persistence (Hopper 1991), according to which features of the lexical source of a grammaticalizing morpheme may 
continue to influence and restrict the grammatical distribution of the item at later stages of its development. As to $a$, persistence is detected in the binding relationship between the object marker and human entities which derives from the original use of topicalizing $a(d)$ with human-referring personal pronouns.

Secondly, the differential treatment of human beings has to be situated within the context of the language system as a whole. Spanish syntax is highly sensitive to semantic distinctions (Melis/Flores 2013) and exhibits a whole range of phenomena that are similarly regulated by a human vs. non-human opposition. The division between persons and things permeates Spanish grammar (Narbona Jiménez 1989, 106-107) to such an extent that it has come to be regarded as an essential and defining property of the language (Lapesa 1968). ${ }^{16}$

Before I close this paper, I have to emphasize that Spanish DOM has functioned as a dynamic and complex system of split case alternations throughout its history, fundamentally dependent on properties of the direct object, but simultaneously influenced by additional parameters in a secondary way (for an overview, cf. Fábregas 2013). Among these, the effect of verbal semantics on the patterns of $a$-marking has attracted special attention (García García 2018). ${ }^{17}$ In particular, when the verbal parameter is explored, the focus comes to be placed on the involvement of the object in the designated event. Role properties, however, are approached from two distinct, if not opposite, vantage points. ${ }^{18}$

On the one hand, DOM is assumed to mark highly affected direct objects. This view relates to the so-called "indexing" or "characterizing" function of case marking (Malchukov/de Swart 2009; Siewierska/Bakker 2009). Case forms of this nature encode semantic roles and are normally associated with oblique arguments. When the indexing function is extended to DOM, with an appeal to Hopper/Thompson's (1980) model of transitivity, it is argued that DOM has a preference for objects which conform to the canon of high transitivity, the property of high affectedness being what defines the semantic role of such objects (Næss 2004). ${ }^{19}$ The relevance of affectedness for $a$-marking in Spanish has been

16 It is worth pointing out that modern Spanish exhibits a phenomenon of Differential Goal Marking (Kittilä 2008), associated with the use of a whole series of special markers serving to contrast human with non-human landmarks (Melis/Rodríguez Cortés 2017).

17 The connections between DOM and verbal semantics are motivating a growing body of cross-linguistic research (Malchukov/de Hoop 2011; Iemmolo/Klumpp 2014; Witzlack-Makarevich/ Seržant 2018).

18 But cf. de Swart (2006) for an attempt to reconcile the two approaches in terms of a principle of "minimal semantic distinctness".

19 Under this proposal, the feature of high affectedness is expected to correlate with definiteness, to the extent that "[a]n action can be more effectively transferred to a patient which is individuated than to one which is not" (Hopper/Thompson 1980, 253; cf. Næss 2004, 1191), and 
noted in various studies (Torrego Salcedo 1999; cf. García García 2018 for more references) and has been the topic of fine grained diachronic analyses (von Heusinger/Kaiser 2007; 2011; von Heusinger 2008), which show, via correlations established between degrees of affectedness and particular verbal classes, that the role dimension has a certain impact on the uses of DOM, subordinated to the workings of the definiteness scale.

On the other hand, the role features of the direct object are inspected through the lens of the distinguishing or discriminatory view of case marking (Malchukov/de Swart 2009; Siewierska/Bakker 2009). Here the assumption is that DOM selects objects whose properties resemble those of subjects and sets them apart from canonical patients, for example, when the direct object referent - a human being and sometimes an inanimate entity - demonstrates a certain level of agentlike activity or is conceived of as a relatively autonomous participant (Hatcher 1942; Weissenrieder 1985; 1991; Delbecque 2002; García García 2007; 2014; 2018; Primus 2012). That is to say, instead of highlighting prototypical transitive objects, as claimed under the former approach, on this view DOM signals atypical, deviant, and in this sense marked objects.

Independently of the theory one chooses to adhere to, it is safe to conjecture that Spanish DOM might be sensitive to event semantics. The influence of role distinctions on Spanish syntax is a pervasive phenomenon (e.g. García-Miguel 2015), and other instantiations of DOM in Spanish, which for reasons of space could not be treated in the present paper, have been argued to depend on evaluations of the role of the object participant in the verbal situation..$^{20}$

\section{Conclusions}

Research on DOM in Spanish has generated a multiplicity of proposals seeking to identify the driving forces behind $a$-marking within a system in which unquestionable regularities coexist with a host of variable choices. From a diachronic perspective, the spread of $a$ to an ever-widening range of principally human objects, observed in textual materials, has been described in terms of a gradual

\footnotetext{
further carries an implication of animacy because "effects on human or animate entities are perceived as more dramatic, more significant, than effects on inanimates" (Næss 2004, 1202). From these correlations the explanation of why DOM prefers animate and definite objects follows naturally (Næss 2004, 1203).

20 I am referring to the phenomena known as leísmo (Flores 2002; Flores/Melis 2007) and clitic doubling (Melis 2018).
} 
movement downward along the hierarchy of definiteness, whose outcome was a situation of obligatory marking on nearly all human objects. A notion of topicality is sometimes introduced into the historical panorama, especially when scholars concentrate on the older stages of the grammaticalization process, but it is fair to say that the issue of how topical values gave way to referential properties in determining DOM has not properly been addressed.

The central aim of the present chapter was to gain deeper insight into the early uses of $a$-marking which were instrumental in orienting subsequent developments. We adopted the well-founded hypothesis that the origin of Spanish DOM had to be tied to a topicalizing structure inherited from Latin and we examined the expansion of grammaticalizing $a$ toward personal pronouns, then proper names, and finally common nouns of human reference. The small steps involved in this progression were subjected to critical analysis; pinpointing the specific properties the $a$-marker was growing sensitive to while moving from one context to another was our primary concern. This enabled us to trace a sequence of functional changes, grounded in analogical relationships, which led from a topic-marker to a definiteness-marker through mediating features of discourse prominence, salient individuation, and singularity.

The idea defended in this paper is that appealing to a notion of topicality may turn out to be necessary to account for the operation of DOM in some or perhaps many languages. As argued in the literature, pragmatic constraints linked to information structure will have a tendency to weigh more heavily in early phases, giving place to semantic factors later in time. Such a scenario is consistent with what is known about the role communicative goals and subjective perspectives play in shaping grammars.

In the case of Spanish, the strong personal pronouns supplied clear evidence that DOM did not arise as a strategy to resolve syntactic ambiguity. But this fact does not invalidate the view held by many scholars that the basic function of DOM has to do with distinguishing objects. The entities set apart by DOM have special properties which oppose them to the regular exponents of the direct object category and approximate them to participants expected to appear as clausal subjects. The discriminating task of DOM consists in enhancing the marked profile of the items in question. Evidently, languages will vary considerably with respect to how these marked properties are defined. The bundle of characteristics commonly associated with subject arguments - topical, animate, individuated, definite, agentive, autonomous, etc. - guarantees the manifestation of variable DOM patterns within and across languages. Of particular interest in this regard was the opportunity the evolutionary history of $a$ gave us to watch the integration of a growing spectrum of features conceived of as subject-like and hence distinguished by DOM. 


\section{Bibliography}

Aissen, Judith, Differential Object Marking. Iconicity vs. economy, Natural Language and Linguistic Theory 21 (2003), 435-483.

Anagnostopoulou, Elena, Conditions on clitic doubling in Greek, in: van Riemsdijk, Henk (ed.), Clitics in the languages of Europe, vol. 20, Berlin/New York, de Gruyter, 1999, 761-798.

Bárány, András, DOM and dative. Morphology or syntax, Invited talk at SyntaxLab, 26 April, University of Cambridge, Cambridge, 2016.

Belloro, Valeria, Spanish clitic doubling. A study of the syntax-pragmatics interface, PhD Thesis, Buffalo, State University of New York, 2007.

Bickel, Balthasar/Witzlak-Makarevich, Alena, Referential scales and case alignment. Reviewing the typological evidence, in: Malchukov Andrej L./Richards, Marc (edd.), Scales, Leipzig, Institut für Linguistik, 2008, 1-37.

Bickel, Balthasar/Witzlak-Makarevich, Alena/Zakharko, Taras, Typological evidence against universal effects of referential scales on case alignment, in: Bornkessel-Schlesewsky, Ina/ Malchukov, Andrej L./Richards, Marc D. (edd.), Scales and hierarchies. A cross-disciplinary perspective, Berlin/Boston, de Gruyter, 2015, 7-43.

Bossong, Georg, Empirische Universalienforschung. Differentielle Objektmarkierung in den neuiranischen Sprachen, Tübingen, Gunter Narr, 1985.

Bossong, Georg, Differential Object Marking in Romance and beyond, in: Wanner, Dieter/ Kibbee, Douglas A. (edd.), New analyses in Romance linguistics. Selected papers from the Linguistic Symposium on Romance Languages XVIII, Urbana-Champaign, April 7-9, 1988, Amsterdam/Philadelphia, John Benjamins, 1991, 143-170.

Bossong, Georg, Le marquage différentiel de l'objet dans les langues d'Europe, in: Feuillet, Jack (ed.), Actance et valence dans les langues de l'Europe, vol. 20, Berlin/New York, de Gruyter, 1998, 193-258.

Chafe, Wallace, Cognitive constraints on information flow, in: Tomlin, Russell S. (ed.), Coherence and grounding in discourse, Amsterdam/Philadelphia, John Benjamins, 1987, 21-52.

Company Company, Concepción, El avance diacrónico de la marcación prepositiva en objetos directos inanimados, in: Bernabé Pajares, Alberto, et al. (edd.), Presente y futuro de la lingüística en España. La Sociedad de Lingüística, 30 años después. Actas del II Congreso de la Sociedad Española de Lingüística, vol. 2, Madrid, Consejo Superior de Investigaciones Científicas, 2002, 146-154 (= 2002a).

Company Company, Concepción, Grammaticalization and category weakness, in: Wischer, Ilse/Diewald, Gabriele (edd.), New reflections on grammaticalization, Amsterdam/ Philadelphia, John Benjamins, 2002, 201-215 (= 2002b).

Comrie, Bernard, Definite and animate direct objects. A natural class, Linguistica Silesiana 3 (1979), 13-21.

Comrie, Bernard, Language universals and linguistic typology, Oxford, Blackwell, ${ }^{2} 1989$.

Dalrymple, Mary/Nikolaeva, Irina, Objects and information structure, Cambridge, Cambridge University Press, 2011.

De Smet, Hendrik, The course of actualization, Language 88:3 (2012), 601-633.

de Swart, Peter, Case markedness, in: Kulikov, Leonid/Malchukov, Andrej/de Swart, Peter (edd.), Case, valency and transitivity, Amsterdam/Philadelphia, John Benjamins, 2006, 249-267. 
de Swart, Peter, Cross-linguistic variation in object marking, PhD Thesis, Radboud University Nijmegen, LOT Publications, 2007.

DeLancey, Scott, An interpretation of split ergativity and related patterns, Language 57:3 (1981), 626-657.

Delbecque, Nicole, A construction grammar approach to transitivity in Spanish, in: Davidse, Kristin/Lamiroy, Béatrice (edd.), The nominative \& accusative and their counterparts, Amsterdam/Philadelphia, John Benjamins, 2002, 81-130.

Escandell Vidal, Victoria, Differential Object Marking and topicality. The case of Balearic Catalan, Studies in Language 33:4 (2009), 832-885.

Fábregas, Antonio, Differential Object Marking in Spanish. State of the art, Borealis 2:2 (2013), 1-80.

Fernández Ramírez, Salvador, Un proceso lingüístico en marcha, in: Presente y futuro de la lengua española. Actas de la Asamblea de Filología del I Congreso de Instituciones Hispánicas, vol. 2, Madrid, Cultura Hispánica, 1964, 277-285.

Fischer, Olga, An inquiry into unidirectionality as a foundational element of grammaticalization. On the role played by analogy and the synchronic grammar system in processes of language change, Studies in Language 37 (2013), 515-533.

Flores, Marcela, Leísmo, laísmo, loísmo. Sus orígenes y evolución, Mexico, UNAM, 2002.

Flores, Marcela/Melis, Chantal, El leísmo desde la perspectiva del "marcado diferencial del objeto", Revista de Historia de la Lengua Española 2 (2007), 83-107.

Folgar, Carlos, Diacronía de los objetos directo e indirecto (del latín al castellano medieval), Santiago de Compostela, Universidade de Santiago de Compostela, 1993.

García García, Marco, Differential Object Marking with inanimate objects, in: Kaiser, Georg A./Leonetti, Manuel (edd.), Proceedings of the workshop "Definiteness, Specificity and Animacy in Ibero-Romance Languages", Arbeitspapier 122, Konstanz, Fachbereich Sprachwissenschaft der Universität Konstanz, 2007, 63-84.

García García, Marco, Differentielle Objektmarkierung bei unbelebten Objekten im Spanischen, Berlin/Boston, de Gruyter, 2014.

García García, Marco, Nominal and verbal parameters in the diachrony of Differential Object Marking in Spanish, in: Seržant, Ilja A./Witzlack-Makarevich, Alena (edd.), Diachrony of Differential Argument Marking, Berlin, Language Science Press, 2018, 209-242.

García-Miguel, José María, Variable coding and object alignment in Spanish. Some corpus-based evidence, Folia Linguistica 49 (2015), 205-256.

García, Érica/van Putte, Florimon, Forms are silver, nothing is gold, Folia Linguistica Historica 8:1 (1987), 365-384.

Givón, Talmy, Introduction, in: Givón, Talmy (ed.), Topic continuity in discourse. A quantitative cross-language study, Amsterdam/Philadelphia, John Benjamins, 1983, 5-41.

Harris, Martin, The evolution of French syntax. A comparative approach, London/New York, Longman, 1978.

Hatcher, Anna G., The use of " $a$ " as a designation of the personal accusative in Spanish, Modern Language Notes 57 (1942), 421-429.

Hopper, Paul J./Thompson, Sandra A., Transitivity in grammar and discourse, Language 56:2 (1980), 251-299.

Hopper, Paul J., On some principles of grammaticization, in: Traugott, Elizabeth C./Heine, Bernd (edd.), Approaches to grammaticalization, vol. 1, Amsterdam/Philadelphia, John Benjamins, 1991, 17-35. 
Iemmolo, Giorgio, Topicality and Differential Object Marking. Evidence from Romance and beyond, Studies in Language 34 (2010), 239-272.

lemmolo, Giorgio/Klumpp, Gerson, Introduction to the special issue "Differential Object Marking. Theoretical and empirical issues", Linguistics 52 (2014), 271-279.

Kittilä, Seppo, Animacy effects on differential goal marking, Linguistic Typology 12 (2008), 245-268.

Kliffer, Michael D., Personal “a”, kinesis and individuation, in: Baldi, Philip (ed.), Papers from the XII Linguistic Symposium on Romance Languages, Amsterdam/Philadelphia, John Benjamins, 1984, 195-216.

Laca, Brenda, Sobre el uso del acusativo preposicional en español, in: Pensado, Carmen (ed.), El complemento directo preposicional, Madrid, Visor, 1995, 61-91.

Laca, Brenda, El objeto directo. La marcación preposicional, in: Company Company, Concepción (ed.), Sintaxis histórica de la lengua española. Primera parte: La frase verbal, vol. 1, México DF, UNAM/Fondo de Cultura Económica, 2006, 423-475.

Lambrecht, Knud, Information structure and sentence form. Topic, focus and the mental representations of discourse referents, Cambridge, Cambridge University Press, 1994.

Lapesa, Rafael, Evolución sintáctica y forma lingüística interior en español, in: Quilis, Antonio/ Carril Blanco, Ramón/Cantarero, Margarita (edd.), Actas del XI Congreso Internacional de Lingüística y Filología Románicas (Madrid, 1-9 septiembre 1965), vol. 1, Madrid, Revista de Filología Española, 1968, 131-150.

Lazard, Gilbert, Actancy, Berlin/New York, de Gruyter, 1998.

Leonetti, Manuel, Specificity and Differential Object Marking in Spanish, Catalan Journal of Linguistics 3:1 (2004), 75-114.

Lichtenberk, Frantisek, On the gradualness of grammaticalization, in: Traugott, Elizabeth C./ Heine, Bernd (edd.), Approaches to grammaticalization, vol. 1, Amsterdam/Philadelphia, John Benjamins, 1991, 37-80.

Luján, Marta, Expresión y omisión del pronombre personal, in: Bosque, Ignacio/Demonte, Violeta (edd.), Gramática descriptiva de la lengua española, vol. 1, Madrid, Espasa Calpe, 1999, 1275-1315.

Malchukov, Andrej, Animacy and asymmetries in differential case marking, Lingua 118 (2008), 203-221.

Malchukov, Andrej/de Swart, Peter, Differential case marking and actancy variations, in: Malchukov, Andrej/Spencer, Andrew (edd.), The Oxford handbook of case, Oxford, Oxford University Press, 2009, 339-355.

Malchukov, Andrej/de Hoop, Helen, Tense, aspect, and mood based differential case marking, Lingua 121 (2011), 35-47.

Meier, Harri, Sobre as origens do acusativo preposicional nas línguas românicas, in: Meier, Harri (ed.), Ensaios de filologia românica, Lisboa, Edição da "Revista de Portugal”, 1948, 115-164.

Melis, Chantal, El objeto directo personal en "El Cantar de Mio Cid". Estudio sintácticopragmático, in: Pensado, Carmen (ed.), El complemento directo preposicional, Madrid, Visor, 1995, 133-163.

Melis, Chantal/Flores, Marcela, On the historical expansion of non-canonically marked "subjects" in Spanish, in: Seržant, Ilja A./Kulikov, Leonid (edd.), The diachronic typology of non-canonical subjects, Amsterdam/Philadelphia, John Benjamins, 2013, 163-184.

Melis, Chantal/Rodríguez Cortés, Diego, El marcado diferencial de la función “meta” en español, Verba 44 (2017), 195-230. 
Melis, Chantal, Spanish indexing DOM, topicality, and the case hierarchy, in: Seržant, Ilja A./ Witzlack-Makarevich, Alena (edd.), Diachrony of Differential Argument Marking, Berlin, Language Science Press, 2018, 97-128.

Menéndez Pidal, Ramón, Cantar de mio Cid, vol. 1, Madrid, Espasa Calpe, 1964.

Monedero Carrillo de Albornoz, Carmen, El objeto directo preposicional y la estilística épica (Nombres geográficos en el "Cantar de Mio Cid"), Verba 5 (1978), 259-303.

Montaner, Alberto (ed.), Cantar de mio Cid. Estudio preliminar de Francisco Rico, Barcelona, Crítica, ${ }^{2} 1993$.

Müller, Bodo, Das morphemmarkierte Satzobjekt der romanischen Sprachen (Der sogenannte präpositionale Akkusativ), Zeitschrift für romanische Philologie 87 (1971), 477-519.

Næss, Åshild, What markedness marks. The markedness problem with direct objects, Lingua 114 (2004), 1186-1212.

Narbona Jiménez, Antonio, Sintaxis española. Nuevos y viejos enfoques, Barcelona, Ariel, 1989.

Nikolaeva, Irina, Secondary topic as a relation in information structure, Linguistics 39 (2001), 1-49.

Pensado, Carmen, La creación del complemento directo preposicional y la flexión de los pronombres personales en las lenguas románicas, in: Pensado, Carmen (ed.), El complemento directo preposicional, Madrid, Visor, 1995, 179-233.

Primus, Beatrice, Animacy, generalized semantic roles, and Differential Object Marking, in: Lamers, Monique/de Swart, Peter (edd.), Case, word order, and prominence. Interacting cues in language production and comprehension, Dordrecht, Springer, 2012, 65-90.

Ramsden, Herbert, The use of " $a$ " + personal pronoun in Old Spanish, Bulletin of Hispanic Studies 38 (1961), 42-54.

Rohlfs, Gerhard, Autour de l'accusatif prépositionnel dans les langues romanes, Revue de Linguistique Romane 35 (1971), 312-334.

Seržant, Ilja A., Weak universal forces. The discriminatory function of case in Differential Object Marking systems, in: Schmidtke-Bode, Karsten, et al. (edd.), Explanation in typology. Diachronic sources, functional motivations and the nature of evidence, Berlin, Language Science Press, 2019, 149-178.

Siewierska, Anna, Person, Cambridge, Cambridge University Press, 2004.

Siewierska, Anna/Bakker, Dik, Case and alternative strategies. Word order and agreement marking, in: Malchukov, Andrej/Spencer, Andrew (edd.), The Oxford handbook of case, Oxford, Oxford University Press, 2009, 290-303.

Sinnemäki, Kaius, A typological perspective on Differential Object Marking, Linguistics 52 (2014), 281-313.

Torrego, Esther, El complemento directo preposicional, in: Bosque, Ignacio/Demonte, Violeta (edd.), Gramática descriptiva de la lengua española. Las construcciones sintácticas fundamentales. Relaciones temporales, aspectuales y modales, vol. 2, Madrid, Espasa Calpe, 1999, 1779-1805.

Traugott, Elizabeth C./Trousdale, Graeme, Gradience, gradualness and grammaticalization, in: Traugott, Elizabeth C./Trousdale, Graeme (edd.), Gradience, gradualness and grammaticalization, Amsterdam/Philadelphia, John Benjamins, 2010, 19-44.

von Heusinger, Klaus/Kaiser, Georg A., The interaction of animacy, definiteness and specificity in Spanish, in: von Heusinger, Klaus/Kaiser Georg A. (edd.), Proceedings of the workshop "Semantic and Syntactic Aspects of Specificity in Romance Languages", Konstanz, Fachbereich Sprachwissenschaft der Universität Konstanz, 2003, 41-65. 
von Heusinger, Klaus/Kaiser, Georg A., The evolution of Differential Object Marking in Spanish, in: von Heusinger, Klaus/Kaiser, Georg A./Stark, Elisabeth (edd.), Proceedings of the workshop "Specificity and the Evolution/Emergence of Nominal Determination Systems in Romance", Konstanz, Fachbereich Sprachwissenschaft der Universität Konstanz, 2005, 33-69.

von Heusinger, Klaus/Kaiser, Georg A., Differential Object Marking and the lexical semantics of verbs in Spanish, in: Kaiser, Georg A./Leonetti, Manuel (edd.), Proceedings of the workshop "Definiteness, Specificity and Animacy in Ibero-Romance Languages", Konstanz, Fachbereich Sprachwissenschaft der Universität Konstanz, 2007, 83-109. von Heusinger, Klaus, Verbal semantics and the diachronic development of DOM in Spanish, Probus 20:1 (2008), 1-31.

von Heusinger, Klaus/Kaiser, Georg A., Affectedness and Differential Object Marking in Spanish, Morphology 21:3 (2011), 593-617.

Weissenrieder, Maureen, Exceptional uses of the accusative " $a$ ", Hispania 68 (1985), 393-398. Weissenrieder, Maureen, A functional approach to the accusative "a", Hispania 74 (1991), 146-156.

Witzlack-Makarevich, Alena/Seržant, Ilja A., Differential Argument Marking. Patterns of variation, in: Seržant, Ilja A./Witzlack-Makarevich, Alena (edd.), Diachrony of Differential Argument Marking, Berlin, Language Science Press, 2018, 1-49. 